\title{
ACADEMIC PERFORMANCE EVALUATION OF THE DEPARTMENTS IN ENGINEERING FACULTY OF A UNIVERSITY BY UTILIZING TOPSIS AND FUZZY DELPHI
}

\author{
Oğuz TORAĞAY \\ Engineering Faculty \\ Gazi University \\ Ankara, TURKEY \\ E-mail: mahdi.zadeh@gazi.edu.tr \\ Murat ARIKAN \\ Engineering Faculty \\ Gazi University \\ Ankara, TURKEY \\ E-mail: marikan@gazi.edu.tr
}

\begin{abstract}
The development and competition in educational facilities, are gradually increasing the importance of the quality of service. In order to accommodate this fast process, the educational organisations attempt to increase the quality of their service and to measure their performance. In general, the organisation's performance should not depend only on one criterion, but it should be evaluated basically on multi criteria. In this study, the academic performance of the departments in the Engineering Faculty of Gazi University have been compared by using one of the multi attribute decision making methods, called TOPSIS. In contrast to the most of the previous studies, in this study the necessary criteria for TOPSIS method and their weights were obtained not relatively, but based on the views of the specialists. For this purpose, in order to prevent the loss of information in the areas of the group decision making, linguistic variables have been utilized and criterion weights have been obtained by using a fuzzy Delphi method.
\end{abstract}

Keywords: Performance Evaluation, TOPSIS, Fuzzy Delphi, Linguistic Variables. 


\section{Introduction}

One of the important aspects in any performance evaluation research is to identify the criteria and their weights. In this article, regarding to the importance of issue, by using Delphi method, experts' views were gathered and based on those data, the most important criteria and their weights had been identified. To decrease the loss of information, while working with experts, we used linguistic variables in data gathering process.

\section{Literature Review}

The topic of evaluation is visited in a number of papers; among these is the evaluation of universities efficiency through performance indicators (Ward, 2007) and the method data envelopment analysis (DEA) (Casu \& Thanassoulis, 2006). The primary concern which emerges from this literature centers on the selection and definition of appropriate 'input' and 'output' sets. DEA does not rank among decision making elements instead; it divides them into effective and non-effective ones regarding them in even dualities (Daneshvar \& Erol, 2009). To compensate the shortcoming in the researches aiming to figure out the most affective section of a university ranking its different sections, a hybrid of Analytic Network Process (ANP) and DEA (Daneshvar ve Erol, 2009). In line with this, some university studies using a set of performance indicators were analyzed by multi-criteria decision making techniques. In determining criteria expert opinion must also be addressed. Articles trying to solve this problem using the Delphi method, generally have tried to prevent the loss of information (Ishikawa, 1993). In this context, researchers working to overcome these obstacles by using fuzzy logic have benefited from linguistic variables and fuzzy logic. (Herrera and Martinez, 2000).

\section{Hypotheses/Objectives}

According to the report of academic performance evaluation and quality improvement in 2007 in Turkey, there is an increased demand of high quality education in universities due to the speedy changes in economic and social environments. Because of those changes evaluation and assessment are needed in higher education to provide accountability for funds, to ensure a well trained work force (in this case, effective decision makers in resource use) and to improve the overall success of academic programs (Suskie, 2006; Walker et al., 2004). The results of evaluations and assessments are valuable in gauging department strengths, allowing for better communication and appeal to prospective students, providing useful information for policy development, and important data for funding programs and potential funding groups. So regarding to these facts, performance evaluation and comparison in universities, faculties and other academic units in university, will lead to increase the academic level and efficiency. In this research all the departments in engineering faculty of a big university compared and their performance evaluation has been done.

\section{Research Design/Methodology}

To evaluate the performance of various departments in engineering faculty, TOPSIS method, which is one of the Multi Criteria Decision Making methods, has been chosen. 
IJAHP Article: Mu, Saaty/A Style Guide for Paper Proposals To Be Submitted to the International Symposium of the Analytic Hierarchy Process 2014, Washington D.C., U.S.A.

Moreover, to identify the necessary criteria and those weights based on the opinion of a group of experts, Delphi method, which is one of the group decision making tools, had been selected.

\section{Data/Model Analysis}

This research does not include AHP or ANP methods as the major data analyzer tool but, to be able to evaluate and analyze all the necessary data, which had been obtained from the academic environment of a big university in Turkey, TOPSIS method was used. In addition, experts, whose opinion had been used during the criteria selection process, were selected among academicians in the field who were experienced in management and programming of the academic aspects in university.

\section{Limitations}

After recognizing the main performance criteria and their weights, the biggest tough for our research was gathering the necessary data for the selected criteria. We had to spend a long time to obtain the data, even for one of the criteria, the necessary information could not be obtained and we had to suppose it equal for all the alternatives. Another limitation during our research was the lack of availability of the experts group as they were selected among the academicians in the university.

\section{Conclusions}

Turkish universities try to make their quality standards like the European universities. So they have to figure out their weaknesses and try to fill the gaps. We think that the method which is proposed in this research will help universities to evaluate their units' performance and improve their quality.

\section{Key References}

Suskie, L., A., "Accountability and quality improvement”, in Hernon, P., Dugan, R., E., Schwartz, C., (Eds.), Revisiting Outcomes Assessment, Libraries Unlimited, Westport, CT(2006).

Walvoord, B., "Assessment Clear and Simple: A Practical Guide for Institutions, Departments, and General Education", Jossey-Bass, San Francisco CA, (2004).

Daneshvar, R., B., Erol, S., "A DEA - ANP hybrid Algorithm Approach to Evaluate a University's Performance", International Journal of Basic \& Applied Sciences IJBAS, 9(10): 115-129 (123)(2011).

Ishikawa, A., Amagasa, M., Shiga, T., Tomizawa, G., Tatsuta, R., Mieno, H., "The MaxMin Delphi method and Fuzzy Delphi method via fuzzy integration", Fuzzy Sets and Systems, 55(3): 241-253(1993). 
IJAHP Article: Mu, Saaty/A Style Guide for Paper Proposals To Be Submitted to the International Symposium of the Analytic Hierarchy Process 2014, Washington D.C., U.S.A.

Daneshvar, R., B., "Çok Ölçütlü Karar Verme Süreci İçin VZA-AAS Sıralı Hibrit Algoritmas1 ve Bir Uygulama", Doktora tezi, Gazi Üniversitesi Fen Bilimleri Enstitüsü, Ankara, (2009).

Casu, B., Thanassoulis, E., "Evaluating cost efficiency in central administrative services in UK universities", Omega, 34, 417-426 (2006).

Herrera F., Martínez L., "A 2-Tuple Fuzzy Linguistic Representation Model for Computing with Words”, IEEE Transactions on Fuzzy Systems, Vol. 8, No. 6 (2000).

Ward, D. (2007), Academic values, institutional management, and public policies, Higher Education Management and Policy, 19(2), 1-12 